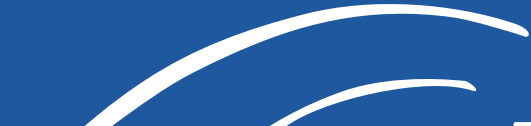 AGUAYTERRTORIO
}

\section{Las represas hidroeléctricas de la región Comahue: expectativas de un desarrollo parcial}

\section{Hydroelectric dams in the Comahue Region: The Expectations of One-Sided Development}

Alfredo Azcoitia

Universidad Nacional de Río Negro. Bariloche, Argentina. alfazkoitia@hotmail.com

Paula Gabriela Núñez

CONICET. Universidad Nacional de Río Negro. Bariloche, Argentina. pnunez@unrn.edu.ar

\begin{abstract}
Resumen - Desde la incorporación del territorio patagónico al Estado Nación, a fines del siglo XIX, se planteó que sus recursos debían de estar al servicio del desarrollo nacional. Desde los años treinta del siglo XX, el aprovechamiento de la fuerza de sus ríos emergió como una referencia en las estrategias de industrialización del país. Los debates en torno a este tema se extenderán y profundizarán durante la década de los sesenta del pasado siglo.

El artículo busca problematizar las representaciones elaboradas sobre el desarrollo de la Norpatagonia durante los años sesenta, contrastando las imágenes sobre el territorio de los documentos oficiales de planificación con los debates que recorren el diario Río Negro. La elección de este periódico se debe a que constituye una de las voces más influyentes de la región y a que, durante la etapa analizada, desplegó una clara estrategia discursiva en favor de los intereses económicos regionales.

Abstract - Since the incorporation of the Patagonian territory to the National State, in the late nineteenth century, it was argued that Patagonia's resources should be employed for national development. Since the 1930s, the tapping the energy of its rivers emerged as a permanent reference in the strategies for the industrialization of the country. Because of this, the notion of development in northern Patagonia is closely linked to the history of the construction of dams in the region, a theme that was much debated during the 1960's.

This article looks at the representations of the development of the North Patagonian region contrasting the images of the territory in the official planning documents with the debates on the subject published in the Newspaper Río Negro. This newspaper was selected as a source because it is one of the most influential voices in northern Patagonia. Furthermore, during 1960s, Río Negro developed a discursive strategy to promote Patagonian economic interests.
\end{abstract}

Palabras clave: Norpatagonia, Desarrollo, Energía Hidroeléctrica, Centralismo, Prensa
Keywords: Northern Patagonia, Economic Development, Hydropower, Centralism, Press

Información Artículo: Recibido: 3 septiembre 2013

Revisado: 25 octubre 2013
Aceptado: 13 febrero 2014 